First publ. in: International Review of Hydrobiology 89 (2004), 3, pp. 229-237

\author{
Axel Dieterich $^{1, *}$ MARTin MörtL $^{1}$ and Reiner ECKMANN ${ }^{1}$ \\ ${ }^{1}$ Limnological Institute, University of Konstanz, D-78457 Konstanz, Germany; \\ e-mail: axel.dieterich@gmx.de
}

\title{
The Effects of Zebra Mussels (Dreissena polymorpha) on the Foraging Success of Eurasian Perch (Perca fluviatilis) and Ruffe (Gymnocephalus cernuus)
}

key words: perch, ruffe, zebra mussel, foraging, habitat complexity

\begin{abstract}
Complex habitat structures can influence the foraging success of fish. Competition for food between fish species can therefore depend on the competitors' abilities to cope with structural complexity. In laboratory experiments, we comparatively assessed effects of zebra mussels (Dreissena polymorpha PALL.) on the foraging success of Eurasian perch (Perca fluviatilis L.) and ruffe (Gymnocephalus cernuиs (L.)). In single-species and mixed-species experiments, the fish were fed caddisfly larvae (Tinodes waeneri (L.)) over complex (mussel-covered stones) and less-complex (bare stones) substrates. With intraspecific competition, food consumption by perch and ruffe decreased significantly when the complex substrate was used. With interspecific competition, food consumption by perch and ruffe did not change with substrate complexity, but perch clearly out-competed ruffe on both substrates. Zebra mussel beds provide a refuge for macrozoobenthos against predation by ruffe and probably also by perch.
\end{abstract}

\section{Introduction}

Habitat structural complexity is an important factor that influences the foraging success of fish (DieHL, 1988; EKLÖv, 1997; WinfIELD et al., 1998). Complex structures, e.g. macrophyte beds, can reduce prey detection because of visual barriers, reduced swimming speed and manoeuvrability, and prey capture rate since attached or hidden prey are more difficult to detect and capture. As a consequence of reduced foraging success, the growth rate of the fish might decrease or the fish might move to alternative habitats (WERNER et al., 1983). Structural complexity can therefore directly or indirectly modify food-web structure in aquatic systems.

When two species compete for food resources in a structurally complex environment, the species' success will depend on its ability to cope with structural complexity. The inferior forager might switch to a less-profitable habitat or, if no alternative habitat is available, will ultimately be out-competed. An example of two fish species known to compete for food resources is Eurasian perch (Perca fluviatilis L.), or its American sister species yellow perch (Perca flavescens), and ruffe (Gymnocephalus cernuus (L.)) (BERGMAN and GreENBERG, 1994; Ogle et al., 1995; Ogle, 1998; Savino and Kolar, 1996). Perch is a visually oriented forager that feeds on zooplankton, macrozoobenthos and fish, mainly from dawn to dusk (BERGMAN, 1988; ERIKSSON, 1978). Ruffe consumes mainly macrozoobenthos (VAN DENSEN, 1985; OGLe et al., 1995; SCHMID, 2000) and, owing to its light-sensitive eyes and particularly to its sensitive cephalic lateral line system, is able to feed during day and night (Disler and SMIRnOv, 1977; Gray and BeSt, 1989).

* Corresponding author 
Ruffe have invaded many lakes in Europe and North America during the last decades (PRATT and Blust, 1992; WinfIELD et al., 1998). In most situations in which ruffe has encountered native Perca populations, concerns about the effect of ruffe on the yields of native perch populations arose. Consequently, studies were initiated to investigate competitive interactions between perch and ruffe (FULLERTON et al., 1998; FULLERTON et al., 2000; SAVINO and KOLAR, 1996), but habitat structural complexity was not explicitly considered in most of these studies.

The importance of macrophytes as complex habitat structures for the foraging efficiency of perch has already been investigated in earlier studies (DIEHL, 1988; WINFIELD, 1986). Recently, MAYER et al. (2001) studied the effects of zebra mussel (Dreissena polymorpha) beds on the foraging of yellow perch because this mussel species is spreading in many North American lakes and provides very complex microhabitats for macrozoobenthos prey organisms. A comparative study on the foraging success of perch and ruffe on Dreissena beds, however, has not yet been reported.

In this study, in laboratory experiments, we compared the foraging success in complex habitats of juvenile perch and ruffe from Lake Constance, Germany. Lake Constance was colonized by Dreissena in the early 1960s (SIESSEGGER, 1969). By the late 1980s, when ruffe was accidentally introduced into the lake, Dreissena was well-established, covering virtually all hard substrates in the littoral. Ruffe became one of the most abundant species in beach seine samples by the mid 1990s (ROESCH and SCHMID, 1996). In this study, structural complexity was represented by bare stones and stones densely covered with zebra mussels. We were particularly interested how structural complexity might affect the two species when they occur in allopatry or in sympatry, and what the consequences for the competition between the two species in nature might be.

\section{Material and Methods}

Juvenile perch ( $68.5 \pm 0.33 \mathrm{~mm}$ total length, $3.2 \pm 0.12 \mathrm{~g}$ wet mass; mean \pm standard error) and ruffe ( $66.4 \pm 0.8 \mathrm{~mm}$ total length, $3.5 \pm 0.13 \mathrm{~g}$ wet mass) were caught with a dip net ( $6 \mathrm{~mm}$ mesh) in the littoral zone of Lake Constance. The fish were separated by species and acclimated to laboratory conditions in 250-L tanks with lake water for up to 1 month; they were fed with zooplankton and chironomid larvae. Four weeks prior to the experiments, the fish were transferred to 25 -L perspex holding tanks (10 fish of one species per tank), which were identical to the experimental tanks. In these holding tanks, the fish were fed ad libitum with frozen chironomid larvae. The photoperiod in the laboratory followed the natural day/night cycle. Temperature during the acclimation period ranged from 12 to $20^{\circ} \mathrm{C}$.

The experimental tanks were placed side by side behind a black curtain to avoid any external disturbance, and cardboard barriers optically separated them from each other. No filters were installed in the tanks, but tanks were equipped with airstones that were removed at the start of an experiment. The substrate consisted of prewashed fine sand. Stones of $40-80 \mathrm{~mm}$ diameter, whose exposed surface was completely covered by live zebra mussels, were sampled from Lake Constance. They were buried in the sandy substrate so that only the mussel-covered part was exposed. The stones were evenly distributed in a single layer, and about $50-60 \%$ of the tank bottom was covered with stones. After the first series of experiments, the stones were cleaned of mussels and were reintroduced into the tanks in the same arrangement as before, for the second series of experiments; the ratio between sandy substrate and stones was the same, but substrate complexity was greatly reduced. Water temperature during the experiments was held constant at $20^{\circ} \mathrm{C}$, and tanks were illuminated $12 \mathrm{~h}$ per day with an intensity of 150 lux at the water surface.

In the experiments, caddisfly larvae (Tinodes waeneri) were used as food. They were obtained from the littoral of Lake Constance by gently brushing them out of their cocoons from within dense Dreissena beds. In preliminary trials, the consumption of $T$. waeneri by both species was evaluated. Two perch or two ruffe were starved for $36 \mathrm{~h}$ in tanks that were identical to the experimental tanks, but contained no substrate. The fish were offered T. waeneri larvae ad libitum and allowed to feed for $2 \mathrm{~h}$. The number of larvae consumed was determined by counting the remaining larvae. These preliminary trials were repeated three times for each species. Two perch consumed 67 larvae on average, while two ruffe 
consumed 46 larvae. Since the fish should not become satiated during an experiment, 50 caddisfly larvae were introduced into each tank with two fish. This should represent a limited food supply since we expected the caddisfly larvae to hide in complex structures (stones or mussel-covered stones); thus, the larvae would not be such an easy prey as those in the tanks without substrate.

The experiments were conducted with either two perch, two ruffe, or one perch plus one ruffe per tank. Ten days before an experiment, the fish were transferred from the holding tanks to the experimental tanks, where they were fed with frozen chironomids for 6 days. Thereafter, they were fed with caddisfly larvae. Prior to an experiment, any remaining larvae were removed from the tank, and the fish were starved for $36 \mathrm{~h}$. Before the start of an experiment, the fish were gently corralled by hand into a glass receptacle $(15 \times 10 \times 15 \mathrm{~cm})$ within the tank to avoid untimely ingestion of prey organisms, and the prey organisms were then released into the tank. After $15 \mathrm{~min}$, the caddisfly larvae had hidden either among zebra mussels or attached to the edge of the bare stones. The experiment was started by slowly inclining the glass receptacle to set the fish free. After $2 \mathrm{~h}$, the fish were removed from the tanks using a dip net and weighed in water. In the single-species experiments, food consumption was determined by counting the remaining larvae and allocating an equal consumption level to both fish. Thus, the fish that were well-adapted to the experimental conditions could be reused in further experiments, but they were not reused until after 4 weeks. In the mixed-species experiments, the fish were immediately killed with $2 \mathrm{mg}$ 1,1,1-trichloro-2-methyl-propanol/L and the larvae per stomach were counted.

The experimental design was full factorial with three factors and one dependent variable. The factors were (1) fish species (two levels: perch and ruffe), (2) substrate (two levels: stones with and without zebra mussels), and (3) type of competition (two levels: intraspecific and interspecific), while the dependent variable was the number of caddisfly larvae consumed per fish. All treatments were repeated five times. Since the data deviated from a normal distribution, nonparametric one-way Kruskal-Wallis-ANOVAs were calculated in Statistica Vers. 5.5, module GLM (StatSoft Inc., 1999). The overall significance level was maintained by a Bonferroni adjustment.

\section{Results}

\subsection{Substrate Effects}

Perch food consumption depended on substrate type. In single-species experiments, consumption decreased significantly from $24.7 \pm 0.2$ caddisfly larvae per fish (mean \pm standard error) in the less-complex substrate to $22.3 \pm 0.6$ caddisfly larvae per fish in the more-complex substrate with zebra mussels (Table 1, Figure 1a). In mixed-species experiments, perch food consumption also differed between the less-complex (36.6 \pm 3.2 caddisfly larvae per fish) and the more-complex substrate (28.2 \pm 3.6 caddisfly larvae per fish), although not significantly so (Table 1, Figure 1c).

Table 1. Competition experiments of perch (Perca fluviatilis) and ruffe (Gymnocephalus cernuus) on a less-complex substrate (stones) and on a more-complex substrate (stones covered with the zebra mussel, Dreissena polymorpha). Results of Kruskal-Wallis-ANOVA. *: Significant p-values after Bonferroni adjustment. $\mathrm{df}=1$.

\begin{tabular}{llccl}
\hline Species & Competition & Substrate & $\mathrm{Chi}^{2}$ & \multicolumn{1}{c}{$p$} \\
\hline Perch & intraspecific & stones/mussel-covered stones & 10 & $0.0016^{*}$ \\
Ruffe & intraspecific & stones/mussel-covered stones & 10 & $0.0016^{*}$ \\
Perch & interspecific & stones/mussel-covered stones & 0.4 & 0.52 \\
Ruffe & interspecific & stones/mussel-covered stones & 0.4 & 0.52 \\
Perch & intraspecific/interspecific & stones & 10 & $0.0016^{*}$ \\
Ruffe & intraspecific/interspecific & stones & 10 & $0.0016^{*}$ \\
Perch & intraspecific/interspecific & mussel-covered stones & 0.4 & 0.52 \\
Ruffe & intraspecific/interspecific & mussel-covered stones & 10 & $0.0016^{*}$ \\
\hline
\end{tabular}




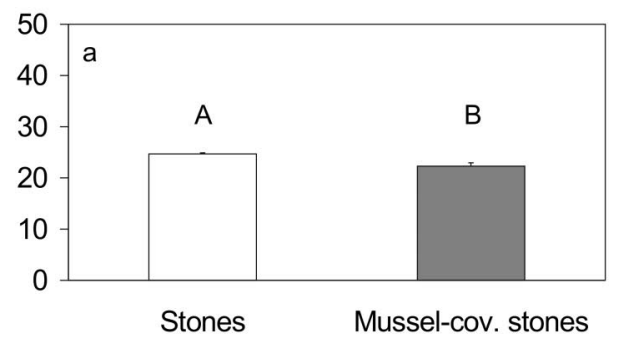

Perch, intraspecific competition

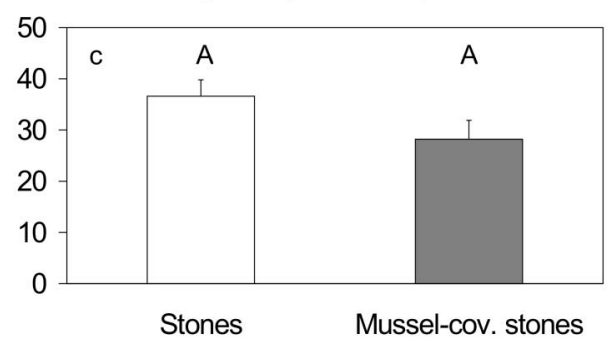

Perch, interspecific competition

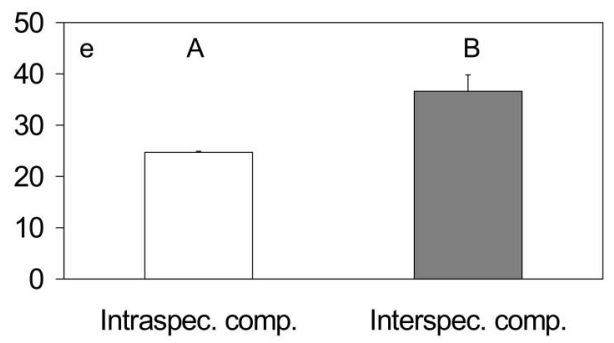

Perch, competition on stones

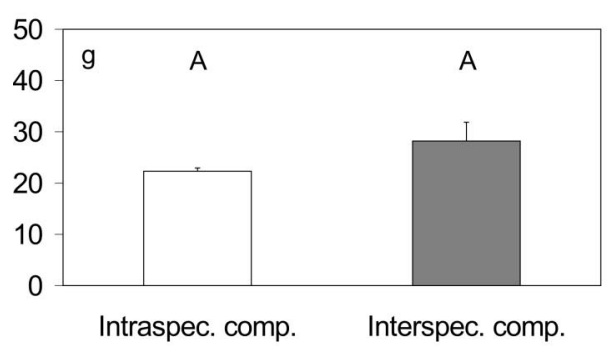

Perch, competition on mussel-covered stones

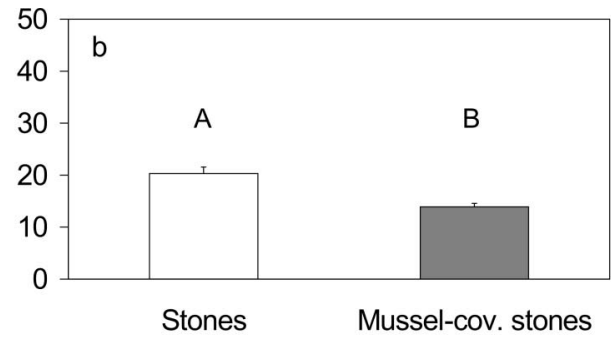

Ruffe, intraspecific competition

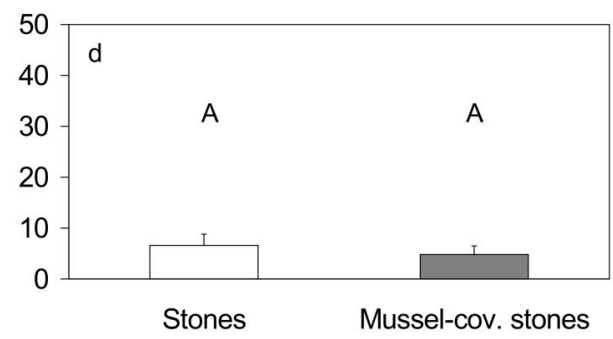

Ruffe, interspecific competition

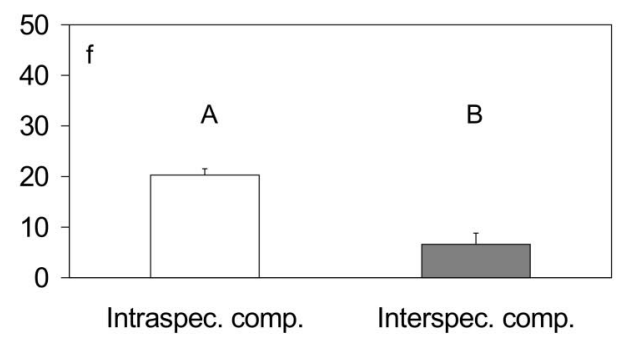

Ruffe, competition on stones

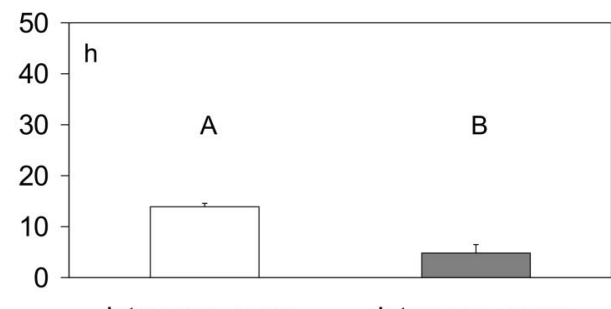

Intraspec. comp. Interspec. comp.

Ruffe, competition on mussel-covered stones

Figure 1a-h. Consumption of Tinodes waeneri by individual perch (Perca fluviatilis) and ruffe (Gymnocephalus cernuus) on a less-complex substrate (stones) and on a more-complex substrate (stones covered with the zebra mussel, Dreissena polymorpha). Panels a-d, effect of substrate; panels e-h, effect of type of competition. Means and standard errors are plotted $(n=5)$. Different letters indicate differences in food consumption within pair-wise comparisons $(p<0.05$, Bonferroni-adjusted). 
Ruffe food consumption also depended on substrate type in single-species experiments, where consumption decreased from $20.3 \pm 1.3$ caddisfly larvae per fish in the less-complex substrate to $13.9 \pm 0.7$ caddisfly larvae per fish in the more-complex substrate (Table 1, Figure 1b). In mixed-species experiments, ruffe food consumption did not depend on substrate complexity, but was significantly lower than in the single-species experiments $(6.6 \pm 2.2$ and $4.8 \pm 1.7$ caddisfly larvae per fish in the less- and more-complex substrate, respectively).

\subsection{Interaction Effects}

Perch food consumption in the less-complex substrate increased significantly from $24.7 \pm 0.2$ caddisfly larvae per fish with intraspecific competition to $36.6 \pm 3.2$ caddisfly larvae per fish with interspecific competition (Table 1, Figure 1e). In the more-complex substrate, food consumption did not differ between intraspecific and interspecific competition (Table 1, Figure 1g).

Ruffe food consumption decreased significantly in both substrates when conditions changed from intraspecific competition to interspecific competition. The consumption decreased from $20.3 \pm 1.3$ to $6.6 \pm 2.2$ caddisfly larvae per fish in the less-complex substrate and from $13.9 \pm 0.7$ to $4.8 \pm 1.7$ caddisfly larvae per fish in the more-complex substrate (Table 1 , Figures $1 \mathrm{f}$ and $\mathrm{h}$ ).

\section{Discussion}

Food consumption of both perch and ruffe depended on substrate complexity and on the type of competition, intraspecific or interspecific. With intraspecific competition, both species consumed less food on the more-complex substrate. Food consumption of ruffe on both substrates differed much more (Figure 1b) than that of perch (Figure 1a), which was statistically significant, but rather small (2.4 larvae per fish). Since virtually all caddisfly larvae on the less-complex substrate were consumed, perch food consumption in these experiments was apparently limited by food supply. Hence, with a higher food supply, consumption by perch on the two substrate types would probably differ more markedly, similar to the results obtained with ruffe. Additionally, it might theoretically have happened that some caddisfly larvae were not recovered with $100 \%$ efficiency in the intraspecific treatment with zebra mussels. That would mean that the numbers of prey items consumed were overestimated, and so the real differences between both substrate types would be even more pronounced.

In a study of food consumption by perch on Dreissena beds, MAYER et al. (2001) observed that yellow perch consume fewer amphipods in the presence of zebra mussels than with a sand substrate. Similar results have been obtained by GoNZALES and DownING (1999) with sunfish (Lepomis macrochirus), whereas no effect of substrate complexity on yellow perch was observed in their study.

The different success of the two species to cope with increased structural complexity in our study seems to be linked with the species' sensory abilities and with their feeding efficiency. Perch, as visually oriented predators, had few problems detecting caddisfly larvae, regardless of whether they were attached to bare stones or hidden in dense mussel beds. By contrast, the very sensitive lateral line system of ruffe was apparently of little help in detecting prey hidden in mussel beds. Ruffe did not display the typical strike-and-glide mode of swimming (JANSSEN, 1997), which they employ when searching for food on a soft substrate. When a ruffe glides, the flow over the membrane-covered lateral line pores is laminar and does not cause a stimulation of the neuromasts. Vibrations caused by prey movement or respiration will then move the membranes and lead to a signal for the neuromasts (JANS- 
SEN, 1997). It is suggested that this system of prey detection is intercepted by the erratic patterns of water flow within and directly above Dreissena beds, which are caused by the mussels' filtration activity. Hence, in these experiments ruffe probably relied on vision for prey detection in the same way as perch. However, although ruffe can use extremely low light levels for vision, their visual acuity is inferior to that of perch (BERGMANN, 1988). Additionally, perch and ruffe differ considerably in prey capture efficiency. Both species ingest prey by suction feeding. However, observations of prey capture in the holding tanks revealed that ruffe in most cases needed several attempts to ingest a caddisfly larva once it was detected, while perch were almost always successful at the first attempt.

In a study by KOLAR et al. (2002), perch consumed less amphipods (Gammarus pseudlimnaeus) than ruffe. The differences in foraging efficiency on bare cobbles compared with cobbles with zebra mussels depended on light conditions. In light, ruffe were the superior competitors on zebra mussels, while in our study perch outperformed ruffe. However, the prey items used by KOLAR et al. were larger and often swim off the bottom, while the caddisfly larvae we used were always confined to the bottom. Additionally, KolaR et al. used shells of dead zebra mussels whereas in our study live mussels were used. Therefore, the conditions for prey detection via the lateral line system differed considerably from those on the present study. This is probably the main reason why ruffe were the superior competitors over complex yet dead substrate, while over Dreissena beds they were outcompeted by perch.

With interspecific competition, food consumption of the two species did not depend on substrate complexity, and perch consumed more than five times more caddisfly larvae than ruffe (Figures 1c and d). Food consumption of perch increased on the less-complex substrate, and ruffe food consumption decreased in parallel. The same occurred on the morecomplex substrate, but the increase of perch food consumption was not significant. This means that, for perch, intraspecific competition was more severe than interspecific competition, and that ruffe was the inferior competitor on both types of substrate.

Since perch were the superior foragers in the present experiments, ruffe would probably be out-competed on more-complex substrates in the wild and might then be forced to switch to an alternative habitat for foraging, i.e. to soft or sandy sediments. Observations on the depth distribution of juvenile perch and of ruffe in Lake Constance support this concept (SCHMID, 2000). During July, significantly more perch were caught from 2-3 $\mathrm{m}$ depth than from below $10 \mathrm{~m}$ depth, while ruffe catches were similarly high at the two depth strata or even higher in the deeper stratum. Below $10 \mathrm{~m}$ depth, the bottom of Lake Constance is generally sandy, while hard substrates prevail at shallower depth. Hence, owing to their depthdistribution patterns, perch are more likely to forage on hard and complex substrates in shallow waters, whereas ruffe forage on soft and less-complex substrates. Additionally, published data by BERGMAN and GREENBERG (1994) and own laboratory studies (DIETERICH et al., in press) show that ruffe feed more efficiently on soft and sandy substrates than perch.

During most of the growing season, hard substrates in the shallow littoral of Lake Constance indeed represent a habitat of high structural complexity owing to the abundance of zebra mussels. After their pelagic larval stage, young Dreissena settle on hard substrates beginning in May (WACKER, 2002) and soon overgrow all suitable substrates, reaching a density and biomass of up to 70,000 ind $\mathrm{m}^{-2}$ and $200 \mathrm{~g}$ tissue dry weight $\mathrm{m}^{-2}$ (BAUMGÄRTNER et al., pers. comm.). Thus, almost all available hard substrates in the littoral are covered with Dreissena from early summer until early winter. During winter, the mussels are harvested by wintering waterfowl (tufted duck, Aythya fuligula; pochards, Aythya ferina; and coots, Fulica atra), which exploit mussel beds down to $11 \mathrm{~m}$ depth until the density and biomass have decreased to 4,100 ind $\mathrm{m}^{-2}$ and $8 \mathrm{~g}$ tissue dry weight $\mathrm{m}^{-2}$ by March (BAUMGÄRTNER et al., pers. comm.). Therefore, during most of the growing season, Dreissena beds represent the single most important complex structure in the littoral of Lake Constance.

At the same time, zebra mussel beds provide an efficient refuge for macrozoobenthos against predation by ruffe and probably also by perch, although consumption by perch dif- 
fered only little but significantly. It has been reported in an earlier study that under conditions of intraspecific competition and high food supply, perch foraging efficiency is higher on sand than on pebbles or gravel (DIETERICH et al., in press). Based on this study, we hypothesize that perch forage more efficiently over sand than over Dreissena clusters, although in the present study, food uptake by perch over sand and over mussel beds was not directly compared. Hence, wherever sandy substrate is available in the shallow littoral, perch will probably switch to this habitat, which provides a clear advantage for prey that are hidden in mussel beds. The higher foraging efficiency of yellow perch over bare sediment as compared with mussel clusters reported by MAYER et al. (2001) concerning Gammarus fasciatus as prey supports this concept, whereas yellow perch showed no differences in foraging efficiency in a study by GoNZALEZ and DownING (1999). But this can be attributed to their use of two amphipod species, the native G. fasciatus and the non indigenous Echinogammarus ischnus. The latter species which did not co-evolve with yellow perch may be more vulnerable to predation than G. fasciatus due to behavioural differences. Additionally the yellow perch used by GoNZALEZ and DownING (1999) were larger and therefore able to disintegrate zebra mussel assemblages. In addition to providing shelter against fish predation, mussel clusters increase the colonisable surface area, and provide a refuge against high currents. In addition, owing to biodeposition by mussels, the availability of organic material is higher. Consequently, in many cases macrozoobenthos abundances increase following the colonization of hard substrates by Dreissena (GRIFFITHS, 1993; MAYER et al., 2002; Mörtl and Rothhaupt, 2003; Stewart and Haynes, 1994).

Caddisfly larvae of the species $T$. waeneri were well-suited for the purpose of the present study. They could easily be sampled from within mussel beds, tolerated handling and laboratory conditions, and were readily accepted as food by both fish species. With their 12-15 mm length, $T$. waeneri larvae were easily observed during an experiment, and the remaining larvae were efficiently recovered after the end of an experiment. When introduced into an experimental tank, they quickly hid among zebra mussels or at the contact zone between sand and the bare stones. During the following $2 \mathrm{~h}$, they could still be picked up by the fish because a protecting cocoon was not built for several hours. Although in Lake Constance $T$. waeneri is not an important prey for perch or for ruffe, it represents a very appropriate model food organism for feeding experiments on complex substrates. Commercially available chironomid larvae, by contrast, did not hide readily and therefore would have been an easy prey for both predators, irrespective of the substrate complexity.

We conclude that Dreissena beds are an effective refuge for macrozoobenthos prey against predation by ruffe and probably also by perch. Both species foraged more efficiently on less-complex substrates. With interspecific competition, perch consumption increased while ruffe consumption decreased, regardless of habitat type.

\section{Acknowledgements}

We thank D. BAUMGÄrTNER and A. WACKER for advice in experimental design and statistics, S. WeRNER and K. SCHÄFER for assistance in the laboratory, and K. A. BRUNE, K.-O. RothHAUPT and two anonymous reviewers for improving the manuscript. This study was supported by Deutsche Forschungsgemeinschaft within the collaborative research centre SFB 454 "Littoral of Lake Constance".

\section{References}

Bergman, E., 1988: Foraging abilities and niche breadths of two percids, Perca fluviatilis and Gymnocephalus cernua, under different environmental conditions. - J. Anim. Ecol. 57: 443-453.

Bergman, E. and L. A. GreEnberg, 1994: Competition between a planktivore, a benthivore, and a species with ontogentic diet shifts. - Ecology 75: 1233-1245. 
DiEHL, S., 1988: Foraging efficiency of three freshwater fishes: effects of structural complexity and light. - Oikos 53: 207-214.

Dieterich, A., D. BAumgärTner and R. ECKMANn, in press: Competition for alternative food between Eurasian perch (Perca fluviatilis.) and ruffe (Gymnocephalus cernuus.) over different substrate types. - Ecology of Fresh water Fish.

Disler, N. N. and S. A. SMIRnov, 1977: Sensory organs of the lateral-line canal system in two percids and their importance in behavior. - J. Fish. Res. Bd. Can. 30: 761-774.

EKLÖV, P., 1997: Effects of habitat complexity and prey abundance on the spatial and temporal distributions of perch (Perca fluviatilis) and pike (Esox lucius). - Can. J. Fish. Aquat. Sci. 54: 1520-1531.

ERIKSSON, L. O., 1978: A laboratory study of diel and annual activity rhythms and vertical distribution in the perch, Perca fluviatilis, at the Arctic circle. - Environ. Biol. Fish. 3: 301-307.

Fullerton, A. H., G. A. Lamberti, D. M. Lodge and M. B. Berg, 1998: Prey preferences of eurasian ruffe and yellow perch: Comparison of laboratory results with composition of Great Lakes benthos. - J. Great Lakes Res. 24: 319-328.

Fullerton, A. H., G. A. Lamberti, D. M. Lodge and F. W. Goetz, 2000: Potential for resource competition between Eurasian ruffe and yellow perch: Growth and RNA responses in laboratory experiments. - Trans. Amer. Fish. Soc. 129: 1331-1339.

GonZALEZ, M. J. and A. Downing, 1999: Mechanisms underlying amphipod responses to zebra mussel (Dreissena polymorpha) invasion and implications for fish-amphipod interactions. - Can. J. Fish. Aquat. Sci. 56: 679-685.

Gray, J. A. B. and A. C. G. Best, 1989: Patterns of excitation of the lateral line of the ruffe. - J. Mar. Biol. Assoc. UK. 69: 289-306.

GRIFFITHS, R. W., 1993: Effects of zebra mussels (Dreissena polymorpha) on the benthic fauna of Lake St. Clair. - In: Nalepa, T. F. and Schloesser, D. W. (eds.): Zebra Mussels. Biology, impacts, and control. p. 415-438. Lewis Publishers, Boca Raton, Florida.

JANSSEN, J., 1997: Comparison of response distance to prey via the lateral line in the ruffe and yellow perch. - J. Fish Biol. 51: 921-930.

Kolar, C. S., A. H. Fullerton, K. M. Martin and G. A. Lamberti, 2002: Interactions among zebra mussel shells, invertebrate prey, and Eurasian ruffe or yellow perch. - J. Great Lakes Res. 28: 664-673.

Mayer, C. M., L. G. Rudstam, E. L. Mills, S. G. CardifF and C. A. Bloom, 2001: Zebra mussels (Dreissena polymorpha), habitat alteration, and yellow perch (Perca flavescens) foraging: systemwide effects and behavioural mechanisms. - Can. J. Fish. Aquat. Sci. 58: 2459-2467.

Mayer, C. M., R. A. Keats, L. G. Rudstam and E. L. Mills, 2002: Scale-dependent effects of zebra mussels on benthic invertebrates in a large eutrophic lake. - J. N. Am. Benthol. Soc. 21: 616-633.

MörtL, M. and K.-O. RothHAuPT, 2003: Intraspecific and interspecific effects of adult Dreissena polymorpha on settling juveniles and associated macroinvertebrates. - Int. Rev. Hydrobiol. 88: 561-569.

Ogle, D. H., J. H. Selgeby, R. M. Newman and M. G. Henry, 1995: Diet and feeding periodicity of ruffe in the St. Louis River Estuary, Lake Superior. - Trans. Amer. Fish. Soc. 124: 356-369.

OGLe, D. H., 1998: A synopsis of the biology and life history of ruffe. - J. Great Lakes Res. 24: $170-185$.

PRATT, D. and W. Blust, 1992: Ruffe, Gymnocephalus cernuus: newly introduced in North America. - Can. J. Fish. Aquat. Sci. 49: 1616-1618.

RoESCH, R. and W. Schmid, 1996: Ruffe (Gymnocephalus cernuus L.), newly introduced into Lake Constance: Preliminary data on population biology and possible effects on whitefish (Coregonus lavaretus L.). - Ann. Zool. Fennici 33: 467-471.

SAvinO, J. F. and C. S. KolaR, 1996: Competition between nonindigenous ruffe and native yellow perch in laboratory studies. - Trans. Amer. Fish. Soc. 125: 562-571.

Schmid, W., 2000: Zur Biologie des Kaulbarschs (Gymnocephalus cernuus (L.)) im Bodensee: Ein Neozoon im Ökosystem. Konstanz. Hartung-Gorre Verlag.

SiessegGer, B., 1969: Vorkommen und Verbreitung von "Dreissena polymorpha Pallas" im Bodensee. - gwf-wasser/abwasser 110: 414-415.

Stewart, T. W. and J. M. HAynes, 1994: Benthic macroinvertebrate communities of southwestern Lake Ontario following invasion of Dreissena. - J. Great Lakes Res. 20: 479-493.

Van Densen, W. L. T., 1985: Feeding behaviour of major 0+ fish species in a shallow, eutrophic lake (Tjeukemeer, The Netherlands). - J. appl. Ichthyol. 2: 49-70. 
WACKER, A, 2002: Effects of biochemical food quality on the recruitment of Dreissena polymorpha in the littoral of Lake Constance: A field study and a laboratory approach. Konstanz. Hartung-Gorre Verlag.

Werner, E. E., G. G. Mittelbach, D. J. Hall and J. F. Gilliam, 1983: Experimental tests of optimal habitat use in fish: the role of relative habitat profitability. - Ecology 64: 1527-1539.

WINFIELD , I. J., 1986: The influence of simulated aquatic macrophytes on the zooplankton consumption rate of juvenile roach, Rutilus rutilus, rudd, Scardinius erythrophthalmus, and perch, Perca fluviatilis. - J. Fish Biol. 29: 37-48.

WiNFIELD, I. J., D. DodGE, and R. Rösch, 1998: Introductions of ruffe, Gymnocephalus cernuus, to new areas of Europe and to North America: history, the present situation and management implications. - In: Cowx, I. D. (eds.): Stocking and introduction of fish in freshwater and marine ecosystems. p. 191-200. Blackwell Sci. Publ., Oxford.

Manuscript received May 26th, 2003; revised January 22nd, 2004; accepted February 16th, 2004 